\title{
Novos horizontes, novas possibilidades
}

Não é difícil perceber, porque também é um fato natural e esperado, o direcionamento dos temas de pesquisas e congressos para as novas possibilidades oferecidas ao meio ortodôntico. Isto fica claro quando observamos a quantidade de títulos ligados aos recursos dos implantes e aos de imagem. Tecnologias estas que, apesar de disponíveis já há algum tempo, têm sua exploração aumentada em decorrência da maior oferta de produtos, bem como domínio do método.

Acompanhando esta corrente mundial, a Revista Dental Press de Ortodontia e Ortopedia Facial tem recebido e publicado os trabalhos deste segmento. Embora, é claro, os assuntos clássicos, que ainda apresentam conceitos a sedimentar, continuem a ser estudados, compondo, também, parte das edições.

Esta edição é aberta por uma imperdivel descrição do estado atual da distração osteogênica, abordagem cada vez mais empregada na Odontologia, mediante a clara explanação do Dr. Faber e colaboradores, que nos permite perceber a abrangência deste recurso. Ainda que citada apenas como uma parte do projeto de doutorado deste primeiro autor, muito nos honra poder documentar uma nova possibilidade de distração osteogênica do ligamento periodontal, abrindo novos horizontes para os pacientes que apresentam defeitos ósseos horizontais associados à migração do tecido gengival.

Também derivado de um projeto de doutorado, Dra. Garib e colaboradores ilustram uma aplicação da tomografia computadorizada (TC) para a avaliação da qualidade óssea vestibular, após o procedimento de expansão rápida da maxila (ERM). É muito provável que, assim como na ERM, nosso nível de conhecimento daquilo que produzimos nos nossos pacientes nos guiará para novas condutas em determinados casos. Esta qualificação tridimensional, permitida por exames como a TC, começa a ditar uma série de pesquisas que revisarão conceitos formulados sobre os limitados exames bidimensionais, com os quais estávamos acostumados.

Desta nova era de procedimentos ortodônticos integrados às novas tecnologias, dois trabalhos sobre a ancoragem "absoluta", um empregando as mini-placas e outro os miniparafusos, apresentam possibilidades de uso destes dispositivos auxiliares. Novos caminhos se abrem aos tratamentos que mostravam-se de alta complexidade.

Ainda compondo esta edição, dois artigos sobre a disfunção temporomandibular nos mantêm atentos a um dos problemas de nosso convívio profissional. E também, como parte do grupo de artigos de temas clássicos, são abordados o tratamento da Classe II com o aparelho de Thurow, a opção de extração de incisivo inferior, o diagnóstico e tratamento de caninos não irrompidos e a interação da Ortodontia com a Fonoaudiologia.

Orgulhosamente, temos como convidado da seção entrevista o professor Jüri Kurol, ilustre personalidade da comunidade ortodôntica européia e mundial que, gentilmente, cedeu esta entrevista, intermediada pelo Prof. David Normando.

Para o Tópico Especial, selecionamos uma revisão sobre a apnéia obstrutiva do sono, que reúne os métodos de tratamentos hoje empregados, situando o ortodontista neste contexto.

Como um retrato do aprimoramento tecnológico, Machado e colaboradores discutem a qualidade atual da fotografia digital, confrontando-a com a convencional. Artigo este que vem consolidar a era da documentação digital, já em curso.

Novos horizontes, novas possibilidades!

Adilson Luiz Ramos Editor 